\title{
The Concept of Cultural Tourism Development of Sanggraloka Sekar Wilis in Ponorogo with A Vernacular Architectural Approach
}

\author{
Eva Elviana *, Erwin Djuni Winarto \\ Architecture, Faculty of Architecture and Design, Universitas Pembangunan Nasional "Veteran" \\ Jawa Timur, Indonesia
}

*Corresponding author:

E-mail:

evaelviana.ar@upnjatim.ac.id

\begin{abstract}
Sanggraloka Sekar Wilis is a tourist spot developed by local people in the village of Kesugihan, Pulung sub-district, Ponorogo. By exploring the beauty of the natural panorama combined with the cool mountain air at the foot of Mount Wilis. Currently, the existing facilities reflect a family tour, but there are no facilities to accommodate cultural arts activities, which are so closely related to the people of Ponorogo. Therefore, it takes a development concept that combines tourist attractions, cultural attractions, and natural beauty. The development concept is manifested in the layout design (layout) and building layout designs that carry the theme of local-traditional architecture (vernacular). This research is included in the qualitative descriptive research category, which describes all the potentials and problems, and performs the qualitative analysis. To explore the culture of the people, the local art of the building (local architecture) and the character of the area were carried out using synchronic reading and diachronic reading techniques. So that the resulting formulation of the concept of cultural tourism development with a vernacular architectural approach. This research was conducted to raise the traditional values and localization of the art of building (vernacular architecture) in the concept of developing facilities to accommodate cultural arts attractions so that the appearance of the building is expected to reflect the locality. The results showed that using vernacular architecture can reflect the identity of the area, and can create harmony with the environment.
\end{abstract}

Keywords: Cultural tourism, vernacular architecture, regional identity

\section{Introduction}

Sanggraloka Sekar Wilis is the name of a tourist spot located in Kesugihan village, Pulung subdistrict, Ponorogo district. The existence of this place is developed by the local community (local), as a means of family tourism (Riyadi in NN, 2018). This is because there are facilities that can be used by all family members, children's play facilities, swimming pools that can be used for children and adults, facilities for footwear therapy for the elderly, sports fields for teenagers, and the existence of a campground that can be used by school students.

Sekar Wilis Resort area is located at the foot of Mount Wilis. With the beauty of the natural panorama combined with the cool mountain air, it is worth exploring with various tourist activities. The existence of natural wealth in the form of shade trees, various shrubs with various flowers and leaf colors, as well as views of rice fields, can give its nuances of beauty. Not to mention the existence of a river that flows at the site, as well as the abundance of clean water sources that are utilized by the existence of a swimming pool, which further adds to the completeness of the facilities here as a means of family recreation.

In addition to tourism activities, the existence of an open field is used by residents with sports activities such as futsal or volleyball, especially during the commemoration of the Independence Day of the Republic of Indonesia, namely there is a match or race, and the use of this area as a

\section{How to cite:}

Elviana, E., \& Winarto, E. D. (2021). The concept of cultural tourism development of Sanggraloka Sekar Wilis In Ponorogo with a vernacular architectural approach. $5^{\text {th }}$ International Seminar of Research Month 2020. NST Proceedings. pages 139-145. doi: 10.11594/ nstp.2021.0920 
camping ground. On the other hand, Sekar Wilis Resort, is also a place for cultural attractions in the form of the "Sekar Wilis Festival", which can attract visitors to come, not only from the surrounding area but also from outside the region (Riyadi in NN, 2018). Even though it is only held in an open field area, this event is much awaited by the local community

The existence of a hall or pavilion building in the Sekar Wilis Resort area is widely used by visitors as a place to sit and relax while enjoying the surrounding natural scenery. This building uses the local Ponorogo (vernacular) architectural style or style, which is a roof form called "Sinom" which is a form of the Limasan roof which was developed to become a typical Ponorogo formation (Susilo, 2018). Roof construction using wood with tile roof coverings. The building is open, like a pavilion/hall in general, with supporting poles made of wood.

Ponorogo Regency is rich in traditions and cultural arts, one of which is the very famous Reog Ponorogo dance culture, in addition to other traditional dances. This should be appreciated so that its sustainability is maintained, by holding cultural arts attractions at every event/activity, so that this art will not be lost and forgotten by people (Priasukmana \& Mulyadin, 2001). However, if you look at the existence of existing facilities at Sekar Wilis Resort, the facilities to support the activities of cultural tourism attractions are not yet available. Therefore it is necessary to provide several supporting facilities so that they can meet the needs, especially if there is a cultural festival event.

In addition to the richness of cultural arts, the people of Ponorogo also have a wealth of traditions in the form of traditional culinary or traditional snacks. It is also unexplored and available in this area. To accommodate these activities, stalls or food and beverage stalls are needed as well as stalls selling typical Ponorogo snacks/souvenirs. To meet the need for these facilities, a building container is needed that is designed using a form and appearance that elevates local values, namely the vernacular Ponorogo architectural style (Hinayana, 2018).

Vernacular Ponorogo architecture is a development of Javanese architecture with a Jogloshaped roof. According to Susilo (2018), the shape of the Joglo roof is varied, thus giving Ponorogo characteristics, which are known by the terms: Bucu, Sinom, Dorogepak, and Srotongan. The following image shows the roof shape model from the Vernacular Ponorogo Architecture:

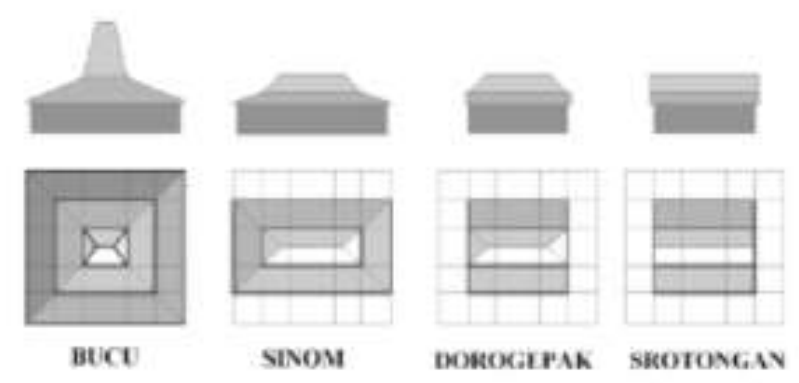

Figure 1. Forms of the roof of the vernacular ponorogo architecture

By using the Vernacular Ponorogo architectural style which is applied to the development of facilities that will be provided in the Sekar Wilis Resort area, it is hoped that it can preserve the local art tradition of building so that it can provide local characteristics and identity, as well as in harmony with the surrounding environment (Susanto, 2018). This is also supported by the existence of abundant natural resources, in the form of wood or bamboo materials, natural stones that are scattered in many locations, as well as the ability and skills of local people in the building. 


\section{Material and Methods}

Referring to the current condition of the Sanggraloka Sekar Wilis tourist area, there are several existing facilities, but several other facilities are still needed as an effort to develop them. By using the in-depth interview method (Faqih, 2007), an illustration of the need for several places to accommodate activities with traditional, artistic, and cultural characteristics was obtained. This qualitative research is then analyzed using the synchronic reading method, namely synchronizing the exploration of the traditional arts and culture of its people, as well as the diachronic reading method, to read the development of the Vernacular Ponorogo Architecture that develops in the community with references from literature (Darjosanjoto, 2006).

Based on the problem analysis, the results were described qualitatively. Namely, to develop the tourist area of Sanggraloka Sekar Wilis, a development concept that combines tourist attractions and cultural attractions are used, combined with natural beauty, with local-traditional themes. For the settlement of the building art, the Vernacular Architecture approach is used, namely architecture that comes from the local tradition and has been developed. To be able to express the characteristics of local locality, this is done by using local styles and materials, so that they can become self-identities and in harmony with the surrounding environment (Wikrawardana, 2009).

\section{Results and Discussion}

To develop the Sekar Wilis Resort tourism area, it is necessary to make efforts to develop it by adding several facilities to accommodate activities to meet needs, which are oriented towards tourist attractions and cultural arts by displaying local identity. The development concept is manifested in the layout design (layout) and building layout design with the theme of local-traditional architecture (vernacular).

\section{Concept of space program}

Based on the results of the analysis of the space requirements program, which is based on the existing conditions of the existing facilities (Duerk, 2008), several facilities can be developed and added, as described in the following table:

Table 1. Spatial program analysis based on existing conditions and development needs

\begin{tabular}{|c|c|c|c|c|}
\hline No & Facility & Description & Activity & User \& Character \\
\hline 1 & Open Space / Field & Existing & $\begin{array}{l}\text { Futsal sports, volleyball, } \\
\text { a place to hold the Sekar } \\
\text { Wilis Festival (art and } \\
\text { culture), a place for } \\
\text { competitions and } \\
\text { celebrations for } \\
\text { independence day, }\end{array}$ & $\begin{array}{l}\text { General visitors of all } \\
\text { ages }\end{array}$ \\
\hline 2 & Camping ground & Existing & $\begin{array}{l}\text { Camping and jamboree } \\
\text { for members of Scouts, } \\
\text { elementary school (SD) } \\
\text { secondary school (SMP) }\end{array}$ & $\begin{array}{l}\text { School visitors / } \\
\text { students }\end{array}$ \\
\hline 3 & Hall / Pendopo & Existing & Seating, relax or chat. & $\begin{array}{l}\text { General visitors of all } \\
\text { age }\end{array}$ \\
\hline 4 & $\begin{array}{l}\text { Foot Therapy Area } \\
\text { To be continued... }\end{array}$ & Existing & $\begin{array}{l}\text { A place to do health } \\
\text { therapy for } \\
\text { footprints/footwear for } \\
\text { visitors who need it }\end{array}$ & $\begin{array}{l}\text { Adult / senior } \\
\text { visitors }\end{array}$ \\
\hline
\end{tabular}




\begin{tabular}{|c|c|c|c|c|}
\hline 5 & $\begin{array}{l}\text { Children's } \\
\text { Playground }\end{array}$ & Existing & $\begin{array}{l}\text { Playground for children } \\
\text { with play tools: swings, } \\
\text { interactive ladders, rope } \\
\text { ladders, slides, etc. }\end{array}$ & $\begin{array}{l}\text { Children / student } \\
\text { visitors }\end{array}$ \\
\hline 6 & Plaza \& Parks & Existing & $\begin{array}{l}\text { A place to gather and } \\
\text { play for teenagers and } \\
\text { children equipped with } \\
\text { various flower plants }\end{array}$ & $\begin{array}{l}\text { General visitors (all } \\
\text { ages) }\end{array}$ \\
\hline 7 & Public toilet & Existing & Place for metabolism & $\begin{array}{l}\text { General visitors and } \\
\text { scout participants }\end{array}$ \\
\hline 8 & Swimming pool & Existing & $\begin{array}{l}\text { Swimming and playing } \\
\text { areas in the pool for } \\
\text { teenagers and children }\end{array}$ & $\begin{array}{l}\text { General visitors } \\
\text { (children and youth) }\end{array}$ \\
\hline 9 & $\begin{array}{l}\text { A place to Rinse and } \\
\text { take a shower }\end{array}$ & $\begin{array}{l}\text { Proposed } \\
\text { development }\end{array}$ & $\begin{array}{l}\text { Complete swimming } \\
\text { pool facilities, as a place } \\
\text { to rinse and play water }\end{array}$ & $\begin{array}{l}\text { Children and youth } \\
\text { visitors }\end{array}$ \\
\hline 10 & $\begin{array}{l}\text { Traditional food \& } \\
\text { drink shops / stalls }\end{array}$ & $\begin{array}{l}\text { Proposed } \\
\text { development }\end{array}$ & $\begin{array}{l}\text { A place to enjoy } \\
\text { traditional culinary } \\
\text { delights (typical food, } \\
\text { snacks, and drinks / } \\
\text { wedhang) }\end{array}$ & $\begin{array}{l}\text { General visitors of all } \\
\text { ages }\end{array}$ \\
\hline 11 & Gift \& souvenir stalls & $\begin{array}{l}\text { Proposed } \\
\text { development }\end{array}$ & $\begin{array}{l}\text { A place to sell Ponorogo } \\
\text { typical snacks/snacks } \\
\text { and souvenirs }\end{array}$ & $\begin{array}{l}\text { General visitors of all } \\
\text { ages }\end{array}$ \\
\hline 12 & Amphitheater seating & $\begin{array}{l}\text { Proposed } \\
\text { development }\end{array}$ & $\begin{array}{l}\text { Seats to enjoy arts and } \\
\text { cultural attractions }\end{array}$ & $\begin{array}{l}\text { General visitors of all } \\
\text { ages }\end{array}$ \\
\hline 13 & $\begin{array}{l}\text { Public Toilet } \\
\text { (additional) }\end{array}$ & $\begin{array}{l}\text { Proposed } \\
\text { development }\end{array}$ & Place for metabolism & $\begin{array}{l}\text { General visitors of all } \\
\text { ages }\end{array}$ \\
\hline 14 & Parkir Kendaraan & $\begin{array}{l}\text { Proposed } \\
\text { development }\end{array}$ & $\begin{array}{l}\text { A place to park motor } \\
\text { vehicles }\end{array}$ & $\begin{array}{l}\text { Visitor Vehicles (two } \\
\text { wheels and four } \\
\text { wheels) }\end{array}$ \\
\hline 15 & Plaza and Gazebo & $\begin{array}{l}\text { Proposed } \\
\text { development }\end{array}$ & $\begin{array}{l}\text { A place to sit around } \\
\text { and enjoy the view }\end{array}$ & $\begin{array}{l}\text { General visitors of all } \\
\text { ages }\end{array}$ \\
\hline
\end{tabular}

Source: Author's Analysis (2020)

Conceptually, the addition of some of these spaces or facilities is based on the character and behavior of everyday society, both traditional and art-cultural activities so that they are included in the local context, such as facilities to enjoy arts-cultural attractions (Reog Ponorogo dance), shops or stalls traditional food and drinks as well as stalls selling traditional snacks/snacks and souvenirs. So that tourist visitors, especially those from outside the city, can enjoy and feel the richness of the archipelago's cultural and culinary arts. 


\section{The concept of shape \& appearance of vernacular architecture}

Ponorogo Regency is rich in traditional house buildings that use traditional architectural styles that have been developed, which is commonly called Vernacular Architecture (Mete, 1990). In general, the roof forms in traditional Ponorogo architectural buildings use the Joglo roof form (which comes from Central Java), which has been developed. Given that the city of Ponorogo is located in the province of West-East Java, the influence of Central Java Joglo is still very strong.

If you look at the development of several added facilities as needed, then the addition of some of these facilities, according to Fadhilah (2016), has an open space character (open space-void) and some have a closed space character (solid-building). In these facilities, the Vernacular Architectural style or style was developed, namely traditional architecture developed and adapted to the conditions of the era. For example, the use of new, modern materials combined with traditional local materials, or using traditional styles and styles.

In the existing (existing) Bale/Pendopo building in the Sanggraloka Sekar Wilis area, it uses the Limasan-Sinom type arap form (Susilo, 2018), with a rectangular building typology, and the building is open, without any walls covering the space. So that the roof of the building functions as a shade, and from inside the building can view the broadest natural panorama in all directions.

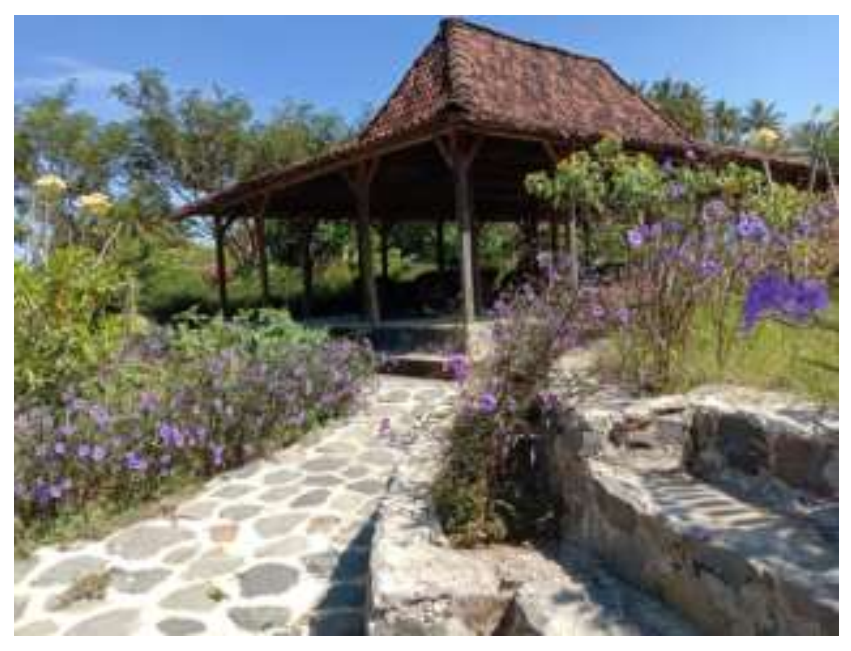

Figure 2. The use of the ponorogo vernacular architectural style in the Bale / Pendopo building

The building concept is designed using vernacular architectural styles. Such as the building of food stalls, hawker stalls, and souvenirs, using a rectangular typology with a roof in the Dorogepak model. With the food and drink sales system in the form of a food court, the food, drink, snack and souvenir stands are made in a group model, with the dining area collected into one, so that the building is open, without dividing walls, only using the columns as support for the roof of the building.

For the public toilet building, the concept of the Srotongan roof is used, with the shape of a rectangular building, developing the form of a saddle roof, into the Srotongan form. Whereas in a square gazebo building, a roof with a Bucu shape can be used. By developing traditional Ponorogo roof forms, it is hoped that they will be able to give characteristics and identity to the building (Wikrawardana, 2009).

\section{Concept of buiding materials}

To promote local values, apart from referring to the tradition of building by the local community, it is also accompanied by the use of local architectural styles and is supported by the use of local materials, so that they are easily available and easily done by local workers. Local materials 
that are widely used by the community and found in the area are natural stone material, widely scattered both in river areas and in rice fields and plantations, in addition to wood and bamboo material (which mostly grows on river banks).

Natural stone can be used for foundations, pavement (macadam), for covering pedestrians or plazas, and for ornament on walls. Meanwhile, wood can be used for columns/poles in buildings and roof frames. For bamboo material, it can be used as a light construction on the roof, as well as gate ornaments, name boards, and so on. While the roof covering material, clay tile roofs are used, which are widely used in community housing.

It is hoped that using this local material will contain economic value and efficiency, as well as ease of work for the local community. Also, the expected final result of the building's appearance with the use of vernacular architecture supported by local materials will create harmony with the appearance of the building with the surrounding environment. The following pictures are ideas for building designs, in the Amphitheatre seating area and Shower and Rinse Place, using local natural stone materials, which are widely found in the area. Here's a visual picture:

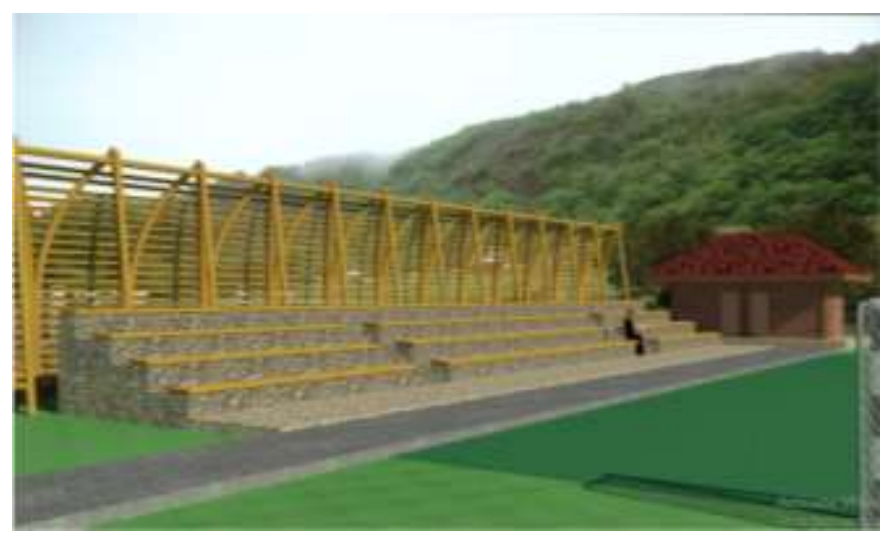

Figure 3. Use of local natural stone materials, on the seat of the Amphitheater

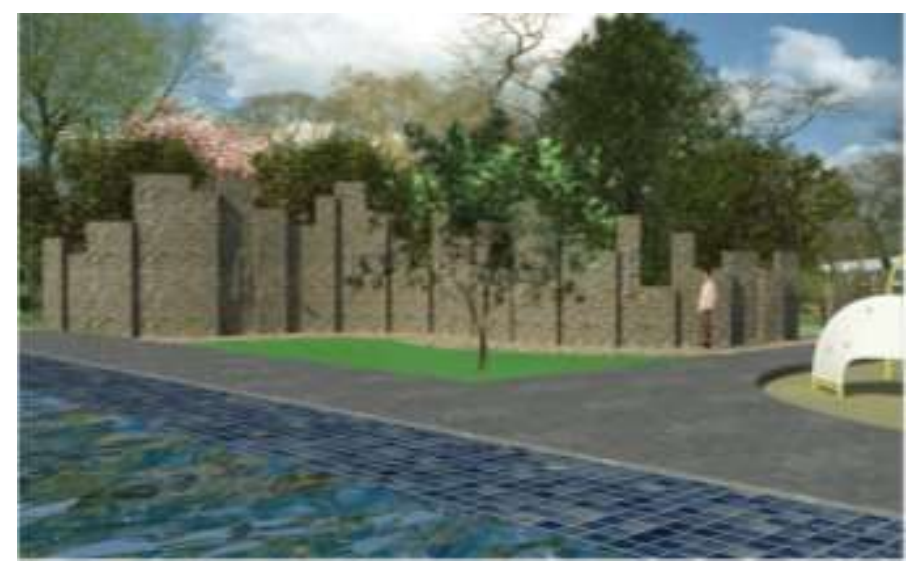

Figure 4. Use of local natural stone materials, in the shower area and shower

\section{Conclusion}

From the description of the problem analysis in the Sekar Wilis resort area, as well as the proposed development design concept, several things can be concluded, namely:

1. To develop a tourist area, it is necessary to pay attention to the potentials that can be explored, both regarding the physical potential of the area, as well as the non-physical potential, of the community's resources. 
2. Mobilizing tourist attractions, sourced from the natural resources owned in an area, combined with the wealth of building arts, uniqueness of cultural arts, and traditional patterns of the people, to provide a good image.

3. By developing these local values, it will give a strong character that can be displayed, so that it can become a characteristic or regional identity.

\section{Acknowledgment}

Praise be to thank Alhamdulillah we always pray to Allah SWT, for all his blessings and guidance, with His permission and permission, the author can complete this research. Awards and gratitude are conveyed to the Institute for Research and Community Service, East Java "Veteran" National Development University, which has funded a research activity entitled "The Concept of Cultural Tourism Development Design in Kesugihan Village, Pulung District, Ponorogo Regency".

Gratitude also goes to the Head of Kesugihan Village and his staff, community leaders who manage the Purwo Ayu Cultural House, and representatives of local youth as resource persons in the Ponorogo area. Do not forget to also express gratitude to fellow students and fellow lecturers at the Department of Architecture, who participated in providing ideas and suggestions, for the completion of this research activity. Finally, I hope this article can provide the benefits of knowledge.

\section{References}

Susilo, A. G. (2018). Model tata masa bangunan rumah tradisional Ponorogo. Jurnal Lingkungan Binaan Indonesia, 7(1), 60-67 DOI: $10.32315 /$ jlbi.7.1.60,

Darjosanjoto, E. T. S. (2006). Penelitian arsitektur di bidang perumahan dan permukiman. Surabaya: ITS Press.

Duerk, D. (2008). Architectural programing. Van Nostrand Reinhold, New York.

Fadhilah, I. (2016). Elemen rancang kota, dunia arsitektur. diunduh pada 23 Maret 2020

Hinayana. (2018). Arsitektur vernakular, arsitektur asli tradisi lokal di Indonesia, interiordesain.id, diunduh 18 Maret 2020

Mete, T. (1990). Vernacular architecture. diunduh pada 18 Maret 2020

NN. (2018,). Sekar wilis festival kesugihan Pulung Ponorogo manjadi destinasi wisata yang indah. GSI News, Portal Berita Masa Kini, diunduh 19 Maret 2020

Priasukmana, S., \& Mulyadin. (2001). Pembangunan Desa Wisata: Pelaksanaan Undang - Undang Otonomi Daerah. Info Sosial Ekonomi, 2(1), 37-44.

Susanto, S. (2018). Arsitektur Vernakular Indonesia: Peran, Fungsi, dan Pelestarian di dalam Masyarakat”, Fakultas Teknik Universitas Indonesia, Jakarta.

Wikrawardana, A. (2009). Membangun identitas kota. http://andryanwikra.wordpress.com/tag/identitas-kota/ . (diakses pada 03 Pebruari 2018) 